\title{
Human Resources Perspective: Intercultural Competence Benefits In Learning English And Japanese Languages Simultaneously
}

\author{
*Girindra Putri Ardana Reswari \\ James Kalimanzila \\ Universitas Diponegoro, Jl. Prof. Sudarto No.13, Tembalang, Kec. Tembalang, Kota Semarang, Jawa Tengah 50275, Indonesia \\ Department of Human Resources, Ministry of Water and irrigation in Tanzania, NBC Bank Mazengo Branch, P. O. Box 456, Dodoma- Tanzania \\ *Corresponding Author. Tel +6285640085518 \\ Email: girindra.reswari@ live.undip.ac.id
}

\begin{abstract}
This research is aiming at discussing the benefits of learning English and Japanese languages simultaneously to cross-cultural competency. This article is also having a further discussion about the human resources development benefits gained from learning the two languages and cultures. English and Japanese are two languages that are famous as foreign languages for international business. It is because The United States, Japan, and the major economic forces of Western Europe are developed countries whose infrastructures and well-established financial markets are conducive to the operation and potential success of multinational corporations (MNCs). This study is a qualitative study with explanatory research as its method. The data gained by analyzing the perceptions drawn from the existing literature of various scholars documented in journals and books connected to Japanese and English languages, as well as human resources development issues. The results showed that learning Japanese and English simultaneously is also a good method in teaching the worker or students that will work in an international setting in having the comprehension of cross-cultural issues in general. The differences of those languages in terms of culture such as direct and indirect behavior in speaking, personal address system, and polite speech will become an example of understanding two different foreign language categories: high and low context cultures.
\end{abstract}

Keywords: Japanese language, English language, cross-cultural, human resources development

\section{Introduction}

Language and human resources development are two things that cannot be separated especially in the international business setting. Language has its role to connect all the employees coming from different backgrounds. Language is also becoming the bridge for the company to build a better relationship with international clients.

To improve human resource development, learning foreign languages is a must.
However, this language learning should also be equipped with learning the culture of the language origin. Kuo and Lai (2006) stated that language and culture are directly correlated since language is the symbol of a country or community. In other words, language is the symbolic presentation of culture. Without involving cultural aspects in language learning, students will find it difficult to master the pragmatic aspects of the language being studied, one of which is the situation of using the language (Deda, 2013). 
English and Japanese are two languages that are famous as foreign languages for international business. It is because The United States, Japan, and the major economic forces of Western Europe are developed countries whose infrastructures and well-established financial markets are conducive to the operation and potential success of multinational corporations (MNCs). Therefore, the success of multinational companies coming from English and Japanese-speaking countries makes those two languages are becoming essential to be mastered.

When we look at the cultural background of both languages, major differences are found. Japanese interactional styles are often thought to reflect these cultural concerns. Thus, it is commonly said that Japanese are very polite; they tend to avoid confrontations in conflict situations; they try not to assert themselves too much (Matsumoto \& Okamoto, 2016).

On the other hand, the English language is mostly believed to belong to western culture in which everything is direct and free. When we compare Japan or other Asian countries, we could say that the English language which belongs to western culture considers less polite.

It is no longer a surprising fact that such kind of obvious differences could lead to a conflict especially when it comes to the professional setting. Hinner (2017) explained that even the same word may not carry the same denotative meaning across cultures and might cause conflict when it comes to communicating interculturally. This situation is even more complex when it involves non-native speakers in intercultural communication (Cheng, 2002).
It is, therefore, this article will discuss the benefits of learning English and Japanese languages simultaneously concerning cross-cultural competency. This article will also discuss further the human resources development benefits gained from learning the two languages and cultures.

The questions that might be raised in this paper are:

1. What are the examples of differences between English and Japanese languages in terms of culture?

2. What are the benefits of learning English and Japanese languages in terms of culture simultaneously?

This paper will also try to answer the research gap of language and culture. It can be seen that researches related to language and culture as a working communication are many. However, only limited researches are talking about the benefit of learning different languages in their relation to the human resources development of every individual.

The example of the previous research related is Burns (2005) who conducted a research on the UAE's cross-border mobility as a one of the world's largest net migration rates, and the number of workers from India, the Philippines, Indonesia, Australia. The result found that although diversity brings some benefits, diversity can also lead to dysfunctional adaptation behaviours and the creation of barriers that reduce the benefits diversity can bring to the organization.

Another example is coming from Kankaanranta \& Planken (2010) who found that even if it comes to multinational company setting, language has been claimed to be the forgotten factor in 
multinational management. The issue of language awareness such as English that is related to social and professional status, appears to be an extremely important but forgotten issue in contemporary business context

\section{Methods}

This research is qualitative research by using the explanatory research method. It is built on perceptions drawn from the analysis of the existing literature of various scholars documented in journals and books connected to Japanese and English languages, as well as human resources development issues. This study adopts an exploratory approach, meaning it aims to: identify what is happening, gain new insights, ask questions, and deal with issues of a qualitative nature (Saunders et al., 2006).

\section{Results and Discussion}

3.1 The examples of differences between English and Japanese languages in terms of culture

Coming from different geographical and historical backgrounds, English and Japanese also have some differences in terms of culture to work as a professional.

Japanese people tend to express things in far more indirect terms than someone in the United States or other direct cultures such as Germany or Switzerland. According to Maekawa et al., (2014) people from high context cultures such as Japan will sometimes choose implicit, nonverbal communication over explicit, verbal communication. They will try to avoid any negative responses and reactions explicitly or verbally. An example of a negative reaction that they will do is silence behavior.

The second significant difference is related to addressing people's behavior. As we know that address people appropriately needs the taking of several factors into consideration, such as the social status or rank of the other, sex, age, family relationship, occupational hierarchy, transactional status, race, or degree of intimacy.

Japanese people are similar to Indonesian. The Japanese seem to use various names or honorific titles as a form of address to avoid using personal pronouns when addressing someone. In Japan, most of the time people call each other by their family name rather than their given names. A Japanese honorific title is a suffix that goes after the person's name as in "Satou (name) san (honorific)" to raise this person (Pizziconi, 2003).

It is similar to Indonesia which has its address system for everyone. In Indonesia, the use of forms of address as expressions is considered a part of politeness.

The English language also has address systems such as Mr/ Ms/Mrs, Madam/ Sir or other honorifics address systems such as Dr, dr, and Professor. However, the significant difference of this difference happens when it allows someone to use the address system in a formal setting only. When it comes to informal settings, calling the name direct is considered normal even if it comes to call the older or higher position person (Afful\& Mwinlaaru, 2013).

Another cultural difference specifically related to business purposes is general polite speech. In Japanese, (敬語 Keigo) can be separated into three aspects: Teineigo ( 丁寧語), Sonkeigo (尊敬語) and Kenjougo (謙譲語). Teineigo uses the lowest level of polite communication with strangers. Meanwhile, Sonkeigo and Kenjougo are similar in the sense that they 
are used to show the conversation partner more respect. Both feature changes in vocabulary use and the addition of honorific prefixes in front of words. However, the two differ in how they are used (Carroll, 2005).

Using Sonkeigo show that the speakers consider whomever they are talking to (or about) to be of a higher status than their selves. On the other hand, with Kenjougo, the speaker might talk about his/her actions (and the of the people belonging to "the group") in a way that shows that the speaker is considering his/her self to be of lower status.

On the other hand, English business does not have specific requirements of language level as Japanese has. English only has formal and informal language, which is formal English will be chosen for the formal setting such as business or working place setting. What the English language might have are only some expressions that differ the formal/ informal communication. For example, the way English speaker says "Go away" that consider not appropriate. Instead, the phrase "Could you give me five minutes?" is chosen as a formal expression that considers more polite and formal (Bhatia \& Bremner, 2012).

\subsection{The benefits of learning English and Japanese languages in terms of culture simultaneously}

Martin \& Varney (2003) argued that the success of communication can also determine the success of relationships and collaboration among people especially inside a team, It is because good communication will provide the message content clarity and avoid ambiguity. However, according to Asuelimen \& Omohimi (2018), some barriers might cause the failure of an effective communication process. Those are:

a. Physical barriers: noise, invisibility, physical problems.

b. Language barriers: graphical mistakes, verbalism, etc.

c. Psychological barriers: anxiety, boredom, nervousness

As language plays a vital role in communication, understanding the language cultural differences of two different foreign languages with a very different culture is needed to be done.

Especially in Indonesia, the term "foreigner" is usually reflected only in western people. People tend to assume that all foreign guests, customers, clients, or even colleagues that come from other countries will have the same culture in terms of speaking and communicating. In contrast with that, Japanese culture is closer to Indonesia compare to western culture.

Thus, learning Japanese and English language and culture will help the learners understand that there are significant differences that might happen in communicating using English or Japanese.

Learning Japanese and English simultaneously is also a good method in teaching the worker or students that will work in an international setting in having the comprehension of cross-cultural issues in general. In 1976, the theory was a theory from Hall related to culture. He mentioned that cultures can be divided into two categories - high context and low context. This theory still exists and is used as training equipment until now (Yang et al., 2020). 
The separation between high and low setting societies is implied to highlight the contrasts in verbal and nonverbal communication. Countries such as Japan, China, France, Spain, Brazil, and more are categorized as high context culture. During the interaction process, people from that culture will not only focus on the words. They will also focus on setting, meaning, and tone.

On the vice versa, low-context cultures such as western cultures as the UK, Australia, and the United States maintain the communication explicitly. They tend to avoid misunderstanding and confusion. In the most extreme cases, leaving any sort of wiggle room for interpretation can be disastrous.

A multinational organization must know the distinction between high and low-context cultures in arrange to communicate successfully and maintain a strategic distance from creating an offensive mistake. A full understanding of these contrasts will successfully make strides in both outward, client-focused communication as well as inter-business connections (Hooker, 2012).

\subsection{Limitation of learning language simultaneously}

Learning two languages that are categorized as foreign languages is not easy. Especially in Japan vs English which has strong differences. For example, Japanese has three completely separate sets of characters, called kanji, hiragana, and katakana, that are used in reading and writing. As well as English that has its tenses.

Therefore, learning Japanese and English simultaneously should be done by not focusing on the skills comprehensions, but more on the language and cultural understanding and competence. If language is viewed as social practice, then culture should become the core of language teaching to the extent that cultural awareness should be viewed as enabling language proficiency (Kramsch, 1993: 8).

\section{Conclusion}

English and Japanese are two languages that are famous as foreign languages for international business. It is because The United States, Japan, and the major economic forces of Western Europe are developed countries whose infrastructures and well-established financial markets are conducive to the operation and potential success of multinational corporations (MNCs). Therefore, the success of multinational companies coming from English and Japanese-speaking countries makes those two languages are becoming essential to be mastered.

Not only to master the language but cultural comprehension behind its languages is also needed to be understood by every individual as part of their human resources development.

Learning Japanese and English simultaneously is also a good method in teaching the worker or students that will work in an international setting in having the comprehension of cross-cultural issues in general. The differences of those languages in terms of culture such as direct and indirect behavior in speaking, personal address system, and polite speech will become an example of understanding two different foreign language categories: high and low context cultures.

\section{REFERENCES}

Afful, J. B. A., \& Mwinlaaru, I. N. (2013). When "Sir" and 'Madam are not: Address terms and reference terms students use for faculty in a Ghanaian university. Sociolinguistic Studies, 6(3), 491-517. 
https://doi.org/10.1558/sols.v6i3.491

Asuelimen, I. B., \& Omohimi, I. M. (2018).

Effective Communication in Human Resources Management. 4(2015).

Bhatia, V. K., \& Bremner, S. (2012). English for business communication. Language Teaching, 45(4), 410-445.

Carroll, T. (2005). Beyond Keigo: smooth communication and the expression of respect in Japanese as a Foreign Language. International Journal of the Sociology of Language, 2005(175-176), 299-313. https://doi.org/10.1515/ijsl.2005.2005.175176.233

Cheng, W. (2002). Intercultural communication between native and nonnative speakers of Title Intercultural communication between native and nonnative speakers of English. http://hdl.handle.net/10722/31105

Deda, N. (2013). The role of Pragmatics in English Language Teaching. Pragmatic Competence. Academic Journal of Interdisciplinary Studies, 2(4), 63-70. https://doi.org/10.5901/ajis.2012.v2n4p63

Hinner, M. B. (2017). Intercultural Misunderstandings: Causes and Solutions. Russian Journal of Linguistics, 21(4), 885909. https://d oi.org/10.22363/2312-91822017-21-4-885-909

Hooker, J. (2012). Cultural Differences in Business Communication. The Handbook of Intercultural Discourse and Communication, January, 389-407. https://doi.org/10.1002/9781118247273.ch 19

Kuo, M.-M., \& Lai, C.-C. (2006). Linguistics across Cultures: The Impact of Culture on Second Language Learning.
Online Submission, 1(1), 1-10.

Maekawa, K., Yamazaki, M., Ogiso, T., Maruyama, T., Ogura, H., Kashino, W., Koiso, H., Yamaguchi, M., Tanaka, M., \& Den, Y. (2014). Balanced corpus of contemporary written Japanese. Language Resources and Evaluation, 48(2), 345-371. https://doi.org/10.1007/s10579-013-9261-0

Martin, B., \& Varney, W. (2003). Nonviolence and Communication. Journal of Peace Research, 40(2), 213-232. https://d oi.org/10.1177/002234330304000 2619

Matsumoto, Y., \& Okamoto, S. (2016). The Construction of the Japanese Language and Culture in Teaching Japanese as a Foreign Language. Japanese Language and Literature, 37(1), 27-48.

Pizziconi, B. (2003). Re-examining politeness, face, and the Japanese language. Journal of Pragmatics, 35(10-11), 15151521.

http://pitt.idm.oclc.org/login?url=http://sea rch.proquest.com/docview/620160533 ?acc ountid=14709\%5Cnhttp://rt4rf9qn2y.searc h.serialssolutions.com/?ctx_ver=Z39.882004\&ctx_enc=info:ofi/enc:UTF-

8\&rfr_id=info:sid/ProQ\%3Apsycinfo\&rft_ val_fmt=info:ofi/fmt:kev:m

Saunders, J. A., Morrow-Howell, N., Spitznagel, E., Dore, P., Proctor, E. K., \& Pescarino, R. (2006). Imputing Missing Data: A Comparison of Methods for Social Work Researchers. Social Work Research, $30(1)$, $19-31$. https://d oi.org/10.1093/swr/30.1.19

Yang, X., Hou, J., \& Arth, Z. W. (2020). Communicating in a proper way: How people from high-/low-context cultures choose their media for communication. International Communication Gazette. 
Kiryoku: Jurnal Studi Kejepangan, Volume 5 No 12021 e-ISSN:2581-0960 p-ISSN: 2599-0497

Tersedia online di http://ejournal.undip.ac.id/index.php/kiryoku

https://doi.org/10.1177/174804852090261

7 